\title{
To survey the effect of working capital policies (investing $\&$ financing) on profitability risk (evidence from Tehran stock exchange)
}

\author{
Mohammad Hassani ${ }^{1, ~ *}$, Arezoo Rajab Tavosi ${ }^{2}$ \\ ${ }^{1}$ Head of Accounting Department, Management \& Social Science Faculty, Islamic Azad University-Tehran North Branch, Tehran, Iran \\ ${ }^{2}$ Master in Accounting, Islamic Azad University-Tehran North Branch, Tehran, Iran
}

\section{Email address:}

m_hassani@iau-tnb.ac.ir(M. Hassani)

\section{To cite this article:}

Mohammad Hassani, Arezoo Rajab Tavosi. To Survey the Effect of Working Capital Policies (Investing \& Financing) on Profitability Risk (Evidence from Tehran Stock Exchange). Journal of Investment and Management. Vol. 3, No. 1, 2014, pp. 30-36.

doi: $10.11648 /$ j.jim.20140301.14

\begin{abstract}
Managers can increase the firm value by using the effective working capital policies. The corporate value maximization strategy is executed with a focus on return and risk. This study investigates the relationship between aggressive/conservative working capital policies and profitability risk in Tehran stock exchange listed companies. The sample includes 274 companies over the period 2006-2012. The results in all industries indicate a negative relationship between working capital investment policy and profitability risk measures. And there is a positive relationship between working capital financing policy and profitability risk measures. It means that, more the companies use conservative working capital policy, it will lead to decreasing profitability risk. And more the companies use aggressive working capital policy, it will lead to increasing profitability risk.
\end{abstract}

Keywords: Profitability Risk, Working Capital, Investment Policy, Financing Policy

\section{Introduction}

One of the most important duties of the companies' management is decision making that affects on all aspects of financial projects. Working capital management is a very important component of corporate finance that deals with current assets and current liabilities. Working capital management is recognized as an important concern of the financial management and the firm management. An effective working capital management contains of programming and controlling of current assets and liabilities in an effective manner that avoiding from risk of short term obligations insolvency and over investment on current assets. Since determination of expenditure and resources composition leads to different risk and return, it's important to determine an effective composition of working capital. Companies can use efficient working capital policies to affect on the firm value. Choosing an effective working capital policy depends on its risk and return.

According to some financial experts' idea, firm value depends more on the management performance, not capital structure. It believes that effective decision making on investment more than financial decision making can lead to increasing profit and share holders' wealth. Contrary to this idea, most financial experts convinced that using liabilities in firm long term finance and paying attention to the liabilities' interest, results in increasing the share holders' wealth.

One of the most important purposes of a company is the maximization of profit in long term. But maintaining of the liquidity is important too, because earning profit versus losing liquidity makes serious problems for the company. So, there must be a balance between these objectives. If a company doesn't pay attention to the profitability, can't run for a long time; And on the other hand, if a company ignore the liquidity issue, it may face insolvency problems. Also according to the inflation problem in Iran, most companies prefer to turn the cash to other assets that leads to the deficiency of liquidity at debt maturities and makes organization unreliable. Lack of working capital in companies that they meet financial exhaustion and finally lead to bankruptcy, it shows the importance of working 
capital management. Accordingly, in this paper we investigate the effect of working capital policies on profitability risk. We used absolute deviation of Return on Assets, Return on Equity, Return on Investment and Return on Capital as the profitability risk measures.

\section{Literature Review}

Working capital is the sum of all firm's current assets that are convertible to cash within a year or less. Net working capital is defined as the difference between current assets and current liabilities. There are different working capital strategies that are combination of current assets and current liabilities strategies. Policies related to current assets are called investment policies and those that related to current liabilities are called financing policies of working capital. These strategies are divided to 3 classes: Conservative Policy, Aggressive Policy and Moderate Policy.

In a conservative policy, the firm maintains huge investment in its current assets, and its liquidity will be very high. Conservatively managed working capital will help lower short term loans that it leads to decreasing the risk of insolvency and bankruptcy. In aggressive policy, the firm tries to use the short term credit with a minimum investment in current assets. An aggressive working capital policy may produce a higher return and the same amount higher risk. And according to lower current assets, it also may lead to liquidity problems.

As regards to the level of current assets and current liabilities, most corporate financial managers choose a working capital policy to balance return and risk. Indeed, they use a moderate policy. If a company uses an aggressive policy for current assets and a conservative policy for current liabilities, or conversely, it uses an aggressive policy for current liabilities and a conservative policy for current assets, it can help to find a balance between risk and return.

Return and profit are common concepts in financial management literature. But what is important is risk of profit and return that shows how much money the firm loses to obtain profit and return. When a company considers risk and return interact with each other, it can demonstrate efficiency of the company's profitability. This study investigates profitability risk that it's defined as the changes of return of profitability. We measured profitability risk by absolute deviation of profitability ratios.

In some studies are as following, the relationship between working capital and profitability or performance had examined; But this study investigates the relationship between working capital policies and profitability risk.

Bardia (1988) found that higher investment in working capital is associated with a decreasing in the firm risk. And great amount of current assets and using a conservative policy leads to lower the firm risk.

Jose et al. (1996) investigated the relationship between aggressive working capital policy and profitability of US firms by using cash conversion cycle as the working capital measures. Results show that there is a negative relationship between cash conversion cycle and profitability. Using more aggressive working capital is associated with higher profitability.

Weinraub \& Vischer (1998) found that there is a significant negative relationship between assets and liability policy in different industries. Moreover, when aggressive working capital policies for assets are followed, they are balanced by conservative working capital policies for liabilities.

Shin and Soenen (1998) and Deloof (2003) examined the relationship between working capital management and profitability in American and Belgian companies. They discovered a negative correlation between cash conversion cycle as the measure of working capital and return on assets. And this negative correlation is different in other industries. Moreover, managers can boost the firm profitability by decreasing of the numbers of day inventory held and decreasing of collection period.

Anand \& Gupta (2001) considered the effect of working capital management on firm's return and risk. Results show that effectiveness working capital management will increase return on investment and decrease corporate risk. Finally, an inefficient management of current assets and liabilities may lead to bankruptcy of many companies.

Lazaridis (2004) studied the relation between working capital management and profitability. Results showed that there is a significant relation between profitability and cash conversion cycle. In addition, managers can increase their profitability by controlling correctly cash conversion cycle and supporting different components of working capital in an optimum level (account receivable, account payable and cashes).

Michalski (2005) investigated the relationship between working capital management and the firm value. He points out that managers fear the negative part of risk of insolvency and they hold more liquidity. He found that managers can enhance the firm value and share holders' wealth by increasing working capital efficiency.

Teruel \& Solano (2005) examined the effect of working capital management on profitability in Spanish firms. They suggested that managers can create value by reducing the firm's number of day's account receivable and inventories and it can improve the firm's profitability.

Annuar et al (2007) studied the relation between working capital management and company's performance. In this study, measuring standard of working capital management has been cash conversion cycle. Results showed that there is a significant relation between cash conversion cycle and company's profitability.

Hassan Pour (2007) examined the effect of working capital strategies on return on investment in Tehran stock exchange listed companies. She concluded that return on investment (ROI) is different in various working capital strategies. And an aggressive working capital strategy will develop the maximum return on investment in all industries. 
Chakraburty (2008) considered working capital in Indian firms and observed that the greater funds blocked in current assets, thereby, reduces the opportunity of investment and profitability. On the other hand, lack of working capital leads the firm to the bankruptcy.

Nazir \& Afza (2008) investigated a relationship between the aggressive/conservative working capital policies and profitability as well as risk of firms for the period of 19982005. The empirical results showed a negative relationship between working capital policies and profitability and they also found no significant relationship between the level of current assets and liabilities and risk of the firms.

Baños-Caballero et al (2008) examined linkage between working capital management and corporate performance. Since a higher investment in working capital can increase firms' sales, a positive relation between working capital and firm value would be expected. However, as working capital increases, a firm's value is also likely to decrease, due to the low return of current assets and the additional financing expenses borne by the firm. Consequently, a negative relation between working capital and firm value might be expected at high levels of working capital. Their findings provide strong support for an inverted U-shaped relation between investment in working capital and firm performance, that is, companies have an optimal working capital level that maximizes their performance. They suggest that investment in working capital is sensitive to financing constraints and showed that the optimal level of working capital is lower for firms more likely to be financially constrained.

Sarniloglu and Demirgunes (2008) studied the effect of working capital management on profitability of the companies. Results showed that account receivables, cashes and financial leverage have affected negatively company's profitability whereas growth of the firm (measured by change of company's sale from one year to another) had a positive effect on company's profitability.

Sing and Pnadi (2008) examined the effect of working capital components on company's profitability. They concluded that current ratio, instantaneous ratio, ratio of working account receivables and ratio of working capital to total assets had a considerable effect.

Mohammad Zadeh \& Nofresti (2009) studied the relationship between working capital strategies and return and risk in chemical and food industries in Iran. The results showed that increase of working capital and decrease of insolvency risk will boost return on investment. But an investment in working capital more than industry average will not result in higher return.

Raheman et al (2010) analyzed the impact of working capital management on firm's performance. The results indicate that the cash conversion cycle, net trade cycle and inventory turnover in days are significantly affecting the performance of the firms. The study also concludes that firms are following conservative working capital management policy and the firms are needed to concentrate and improve their collection and payment policy. The effective policies must be formulated for the individual components of working capital. Furthermore, efficient
Management and financing of working capital (current assets and current liabilities) can increase the operating profitability of manufacturing firms..

Karaduman et al (2010) studied the relation between working capital management and profitability of the company. They used rate of return on assets as a standard of measuring profitability and applied cash conversion cycle as a standard of measuring working capital management. Their findings showed that decreased cash conversion cycle affects positively rate of return on assets. Dong and Sue (2010) studied the relation between working capital management and profitability. Results showed that there is a strong negative relation between profitability and cash conversion cycle meaning that when cash conversion cycle is increased, profitability of the company will be reduced. Therefore managers can increase established value for shareholders by controlling optimally cash conversion cycle and keeping its components in an optimal level.

Gill et al (2010) examined the relation between working capital management and profitability. They concluded that there is a significant relation between gross operational profit and profitability of companies.

Masowa (2010) showed that there is a significant relation between different indices of working capital management and profitability of companies.

Afza and Nazir studied the relation between policies of working capital and profitability. Results showed that there is a negative relation between company profitability and investment on working capital and funding policies.

Rajesh and Reddy (2011) studied the effect of working capital management on profitability. Results showed that components of working capital management are effective on performance of companies.

Ching et al (2011) identified the working capital components that most affect profitability. The profitability was measured in three different ways: return on sales (ROS), on asset (ROA) and on equity (ROE). The independent variables used are cash conversion efficiency, debt ratio, days of working capital, days receivable and days inventory. These results show that regardless the type of company, whether working capital or fixed capital intensive, managing working capital properly is equally important. Moreover, managing inventory as well as cash conversion efficiency to an optimum level will yield more profit in the working capital intensive type of company, while two other different variables create more profit in the fixed capital intensive type of company.

Vural et al (2012) investigated the relationship between working capital management components and performance of the firms. The results demonstrate that firms can increase profitability measured by gross operating profit by shortening collection period of accounts receivable and cash conversion cycle.

\section{Research Hypotheses}

We propose the following hypotheses relating to the measures of profitability risk:

$\mathrm{H}$ : There is a significant relationship between working 
capital policies and profitability risk.

$\mathrm{H}_{1}$ : There is a relationship between working capital policy and absolute deviation of Return on Assets $\left(A D_{R O A}\right)$.

$\mathrm{H}_{2}$ : There is a relationship between working capital policy and absolute deviation of Return on Equity $\left(A D_{R O E}\right)$.

$\mathrm{H}_{3}$ : There is a relationship between working capital policy and absolute deviation of Return on Investment $\left(A D_{R O I}\right)$.

$\mathrm{H}_{4}$ : There is a relationship between working capital policy and absolute deviation of Return on Capital $\left(A D_{R O C}\right)$

\section{Data and Methodology}

This study used a regression method based on panel data collected from the annual reports of selected companies. In this paper, we collected the information about theoretical issues and literature review from the last similar studies and financial books. In statistical analysis portion, required data was collected from Tehran Stock Exchange database. This study investigates the relationship between aggressive/conservative working capital policies and profitability risk in Tehran Stock Exchange listed companies over the period 2006-2012. The samples were chosen considering the following measures and then the final sample includes 274 companies over 6 years period (1644 observations):

* These companies were listed in Tehran Stock Exchange before the year 2006.

* These companies were active in Tehran Stock Exchange between the year 2006 to 2012 and the financial year has not changed in this period.

* The samples were chosen by extracting investment and insurance companies, banks and financial and credit institutions.

\section{Model and Variables}

To capture the effects of working capital policies on profitability risk, we used the following model:

$$
\begin{aligned}
& \text { Profitability Risk }_{\mathrm{i}, \mathrm{t}}= \beta_{0}+\beta_{1} \text { Working Capital Policies }_{\mathrm{i}, \mathrm{t}}+\beta_{\mathrm{n}} \\
& \text { Controls }_{\mathrm{i}, \mathrm{t}}+\varepsilon_{\mathrm{i}, \mathrm{t}}
\end{aligned}
$$

\section{Independent Variables}

One of the independent variables is investment policy. In order to measure investment policy, we used current assets divided by total assets ratio that a lower ratio means a relatively aggressive policy. Aggressive investment policy results in a low level of current assets as percentage of total assets. In contrast, a conservative investment policy has a larger proportion of investment in current assets. To investigate financing policy, we used current assets divided by total assets ratio that a higher ratio means a relatively aggressive policy. An aggressive financing policy involves financing of all current assets and a part of fixed assets with current liabilities. But a conservative financing policy uses more long term liabilities and capital.

\section{Dependent Variables}

In this study, we use Absolute Deviation $\left(\mathrm{AD}^{1}\right.$ ) of Return on Assets (ROA), Return on Equity (ROE), Return on Investment (ROI) and Return on Capital (ROC) as the profitability risk measures.

$\mathrm{ROA}=$ Net income plus financial expenses divided by total assets.

$\mathrm{ROE}=$ Net income divided by stock holders' equity.

ROI $=$ Net income divided by investment.

ROC $=$ Net income divided by capital (stock holders' equity plus total liabilities).

\section{Control Variables}

In this study, we use following control variables:

Size $=$ Logarithm of total assets.

Sales Growth $=$ Sales changes during two consecutive years.

Leverage $=$ Total liabilities divided by total assets.

WCTA $=$ Net working capital divided by total assets.

\section{Statistical Analysis}

Summary of descriptive statistics about variables has been shown in table 1. Average of ROA absolute deviation is 0.0928 that is close to zero. Absolute deviation of return on equity has a mean of 0.4976 . Absolute deviation of return on investment's mean is 0.4710 and absolute deviation of return on capital's mean is 0.09890 .

Investment policy in our sample has an average of $63.23 \%$. It means that 63 percentages of total assets belongs to current assets. It is observed rising in this proportion in the period of 6 years. It shows that the firms try to invest more in working capital and current assets. Financing policy in our sample has an average of $56.51 \%$. It shows that 56 percentages of total assets has been financed from current liabilities. Financing policy also has been rising in this period.

Table 1. Descriptive Statistics

\begin{tabular}{ccccc}
\hline Variables & Mean & Std. Dev. & Skewness & Kurtosis \\
\hline $\mathrm{AD}_{\mathrm{ROA}}$ & 0.0928 & 0.0924 & 3.119 & 20.884 \\
$\mathrm{AD}_{\mathrm{ROE}}$ & 0.4976 & 1.5418 & 10.024 & 114.49 \\
$\mathrm{AD}_{\mathrm{ROI}}$ & 0.4710 & 0.6329 & 5.356 & 43.948 \\
$\mathrm{AD}_{\mathrm{ROC}}$ & 0.0989 & 0.0903 & 1.745 & 6.698 \\
Investment Policy & 0.6323 & 0.2063 & -0.678 & 2.766 \\
(CATA) & & & & \\
Financing Policy & 0.5651 & 0.2538 & 1.963 & 14.837 \\
(CLTA) & 5.6983 & 0.5691 & 0.616 & 3.766 \\
Size & 0.1901 & 0.5672 & 5.253 & 46.174 \\
Sales Growth & 0.6567 & 0.2514 & 1.692 & 11.803 \\
Leverage & 0.0672 & 0.2706 & -1.803 & 14.023 \\
WCTA & & & &
\end{tabular}

Average of size and sales growth is 5.6983 and 0.1901 . It means that we have positive sales growth in this period. Mean of leverage is 0.6567 and average of net working capital is 0.0672 that it shows net working capital is 6

\footnotetext{
${ }^{1}$ Absolute Deviation $=\left|x_{i}-\mu\right|$
} 
percentage of total assets. By investigating skewness in our sample, all variables except investment policy and net working capital have positive skewness. And all variables have positive kurtosis too. In general, all of variables in this sample don't follow a normal distribution.

In this study, we used Pearson correlation coefficient to investigate collinearity between independent variables that is shown in the following table:

Table 2. Correlation Matrix

\begin{tabular}{|c|c|c|c|c|c|c|}
\hline Probability & CATA & CLTA & SIZE & SALEGROWTH & LEVERAGE & WCTA \\
\hline \multirow{2}{*}{ CATA } & 1.000000 & & & & & \\
\hline & ----- & & & & & \\
\hline \multirow{2}{*}{ CLTA } & 0.322197 & 1.000000 & & & & \\
\hline & 0.0000 & ---- & & & & \\
\hline \multirow{2}{*}{ SIZE } & -0.167758 & -0.078450 & 1.000000 & & & \\
\hline & 0.0000 & 0.0015 & ----- & & & \\
\hline \multirow{2}{*}{ SALEGROWTH } & -0.041181 & -0.098701 & 0.069046 & 1.000000 & & \\
\hline & 0.0951 & 0.0001 & 0.0051 & ----- & & \\
\hline \multirow{2}{*}{ LEVERAGE } & 0.122364 & 0.905942 & -0.044976 & -0.090173 & 1.000000 & \\
\hline & 0.0000 & 0.0000 & 0.0683 & 0.0003 & ----- & \\
\hline \multirow{2}{*}{ WCTA } & 0.460267 & -0.692141 & -0.054333 & 0.061164 & -0.756290 & 1.000000 \\
\hline & 0.0000 & 0.0000 & 0.0276 & 0.0131 & 0.0000 & ----- \\
\hline
\end{tabular}

We observed that financing policy is strongly correlated with leverage and net working capital. And there is strong correlation between leverage and net working capital that it's evidence of severe collinearity. Thus, we couldn't enter financing policy, leverage and net working capital variables to this model simultaneously. Therefore, we omitted these two control variables and financing policy is one of the main variables and it stayed in this model. There isn't any strong correlation about other variables.

According to four hypothesis that defined below and profitability risk measures, we have four regression models in this paper. We used panel data methodology to estimate the model. To Specifying that panel data is an efficient method, we used Chow Test. As it's shown in table 3, PValue in all four models are smaller than 0.05 . So we used panel data. And to specify which method (Fixed effects or Random effects method) is more effective, we used Hausman Test. According to the results of Hausman Test in the following table, in all four models $(\mathrm{P}$-Value $<0.05)$ and therefore, we used fixed effects method to estimate the model.

Table 3. Results of Choosing Regression Model

\begin{tabular}{lllll}
\hline Models & $\begin{array}{l}\text { ADROA } \\
\text { Model }\end{array}$ & $\begin{array}{l}\text { ADROE } \\
\text { Model }\end{array}$ & $\begin{array}{l}\text { ADROI } \\
\text { Model }\end{array}$ & $\begin{array}{l}\text { ADROC } \\
\text { Model }\end{array}$ \\
\hline $\begin{array}{l}\text { F-Statistic } \\
\text { (P-Value) }\end{array}$ & 5.844 & 1.456 & 4.989 & 5.482 \\
Chi-Sq. & $(0.0000)$ & $(0.0000)$ & $(0.0000)$ & $(0.0000)$ \\
$\begin{array}{l}\text { Statistic } \\
\text { (P-Value) }\end{array}$ & 15.452 & 66.912 & 31.353 & 11.416 \\
\hline
\end{tabular}

The following table presents results of regression analysis and hypothesis test. It can be observed from table 4 that the value of F-Statistic in each model is $(0.000)$ indicates that the overall model is good and significant with a $95 \%$ level of confidence. R-Square in the first model is approximately $55 \%$. This implies that 55 percentages of variation in absolute deviation of Return on Assets $\left(A D_{R O A}\right)$ is determined by the variables entered to the model. R-
Square in second model is $30.46 \%$. In third model is $56.62 \%$ and in fourth model is approximately $66 \%$. As it clear, the highest coefficient of determination belongs to the fourth model and lowest one is in second model that can assess how well the variables explain the model.

In this study, we used Jarque-Bera test to examine normality of residuals distribution. The results show that the distribution of residuals isn't normal in all four models. But regarding to the large number of observation and the central limit theorem, we can ignore the normality of residuals distribution. As it's shown in table 4, the DurbinWatson statistic is between 1.5 and 2.5 in each model, it implies that the successive values of estimated residuals aren't dependent on each other and there is no autocorrelation problem in the model.

In the first regression model, we assess the relationship between working capital policy and absolute deviation of Return on Assets. According to the results that showed in table 4, P-Value of t-statistic in investment policy and financing policy variables are less than 0.05 , thus, the first model can reject the null hypothesis and there is a significant relationship between working capital policy and $A D_{R O A}$. According to negative $\beta$ coefficient of investment policy variable $(-0.0475)$, there is an inverse relationship between investment policy and $A D_{R O A}$. It means that increasing of investment policy leads to decreasing of $A D_{R O A}$ and finally decreasing of profitability risk. According to positive $\beta$ coefficient of financing policy variable $(0.0314)$, there is a direct relationship between financing policy and $A D_{R O A}$. It means that increasing of financing policy leads to increasing of $A D_{R O A}$ and profitability risk.

In second hypothesis test, we considered the relationship between working capital policy and $A D_{R O E}$. Results show that probability of t-statistic in investment policy $(0.3345)$ is greater than 0.05 and in financing policy $(0.0008)$ is less than 0.05 . In fact, the second model can't reject null hypothesis and there is a relationship only between 
financing policy and $A D_{R O E} \cdot \beta$ coefficient of financing policy variable $(-0.2063)$ is negative and there is an inverse relationship between financing policy and $A D_{R O E}$ that when financing policy increases, profitability risk decreases.

In third hypothesis test, we examine the relationship between working capital policy and $A D_{R O I}$. According to the results presented in table 4 , probability of t-statistic in investment and financing variables are less than 0.05 and alternative hypothesis can be accepted in this model and there is a significant relationship between working capital policy and $A D_{R O I}$. $\beta$ coefficient of investment policy variable $(-0.1686)$ is negative and there is an inverse relationship between investment policy and $A D_{R O I}$. As investment policy increases, $A D_{R O I}$ decreases, in other words, profitability risk will decrease. According to positive $\beta$ coefficient of financing policy variable $(0.1510)$, there is a direct relationship between financing policy and $A D_{R O I}$. And increasing of financing policy leads to increasing of $A D_{R O I}$ and profitability risk.

In fourth regression model, we investigate the relationship between working capital policy and $A D_{R O C}$. Result in table 4 show that probability of t-statistic in investment and financing policy variables are less than 0.05 Therefore, we can reject the null hypothesis and state with a level of $95 \%$ confidence that there is a significant relationship between working capital policy and $A D_{R O C}$. According to negative $\beta$ coefficient of investment policy variable (-0.0386), there is an inverse relationship between investment policy and $A D_{R O C}$ that increase of investment policy leads to decreasing of $A D_{R O C}$. $\beta$ coefficient of financing policy variable $(0.0815)$ is positive, it shows that there is a direct relationship between financing policy and $A D_{R O C}$. By increasing of financing policy, $A D_{R O C}$ and profitability risk will increase.

Table 4. Results of Regression Analysis

\begin{tabular}{|c|c|c|c|c|}
\hline Variables & $\begin{array}{l}\text { AD } D_{\text {ROA }} \\
\text { Model }\end{array}$ & $\begin{array}{l}\text { AD } D_{\text {ROE }} \\
\text { Model }\end{array}$ & $\begin{array}{l}\text { AD } D_{\text {RoI }} \\
\text { Model }\end{array}$ & $\begin{array}{l}\text { AD } D_{\text {ROC }} \\
\text { Model }\end{array}$ \\
\hline $\begin{array}{l}\boldsymbol{C} \\
\text { (t-Statistic) } \\
\text { (P-Value) }\end{array}$ & $\begin{array}{l}0.4612 \\
(9.102) \\
(0.0000)\end{array}$ & $\begin{array}{l}3.1331 \\
(11.297) \\
(0.0000)\end{array}$ & $\begin{array}{l}3.1614 \\
(12.732) \\
(0.0000)\end{array}$ & $\begin{array}{l}0.4839 \\
(9.875) \\
(0.0000)\end{array}$ \\
\hline $\begin{array}{l}\text { Investment } \\
\text { Policy } \\
\text { (t-Statistic) } \\
\text { (P-Value) }\end{array}$ & $\begin{array}{l}-0.0475 \\
(-3.301) \\
(0.0010)\end{array}$ & $\begin{array}{l}-0.0706 \\
(-0.965) \\
(0.3345)\end{array}$ & $\begin{array}{l}-0.1686 \\
(-2.642) \\
(0.0083)\end{array}$ & $\begin{array}{l}-0.0386 \\
(-2.699) \\
(0.0070)\end{array}$ \\
\hline $\begin{array}{l}\text { Financing } \\
\text { Policy } \\
\text { (t-Statistic) } \\
\text { (P-Value) }\end{array}$ & $\begin{array}{l}0.0314 \\
(4.061) \\
(0.0001)\end{array}$ & $\begin{array}{l}-0.2063 \\
(-3.358) \\
(0.0008)\end{array}$ & $\begin{array}{l}0.1510 \\
(4.013) \\
(0.0001)\end{array}$ & $\begin{array}{l}0.0815 \\
(6.968) \\
(0.0000)\end{array}$ \\
\hline $\begin{array}{l}\text { Sales Growth } \\
\text { (t-Statistic) } \\
\text { (P-Value) }\end{array}$ & $\begin{array}{l}-0.0035 \\
(-1.538) \\
(0.1241)\end{array}$ & $\begin{array}{l}0.0076 \\
(0.870) \\
(0.3839)\end{array}$ & $\begin{array}{l}-0.0035 \\
(-0.376) \\
(0.7062)\end{array}$ & $\begin{array}{l}-0.0025 \\
(-1.357) \\
(0.1748)\end{array}$ \\
\hline Size & -0.0623 & -0.4344 & -0.4682 & -0.0712 \\
\hline (t-Statistic) & $(-6.930)$ & $(-8.822)$ & $(-10.818)$ & $(-8.011)$ \\
\hline (P-Value) & $(0.0000)$ & $(0.0000)$ & $(0.0000)$ & $(0.0000)$ \\
\hline R-Squared & 0.5542 & 0.3046 & 0.5662 & 0.6591 \\
\hline $\begin{array}{l}\text { F-Statistic } \\
\text { (P-Value) }\end{array}$ & $\begin{array}{l}6.130 \\
(0.0000)\end{array}$ & $\begin{array}{l}2.161 \\
(0.0000)\end{array}$ & $\begin{array}{l}6.437 \\
(0.0000)\end{array}$ & $\begin{array}{l}9.537 \\
(0.0000)\end{array}$ \\
\hline $\begin{array}{l}\text { Jarque-Bera } \\
(P \text {-Value })\end{array}$ & $\begin{array}{l}76.425 \\
(0.0000)\end{array}$ & $\begin{array}{l}144.50 \\
(0.0000)\end{array}$ & $\begin{array}{l}64.682 \\
(0.0000)\end{array}$ & $\begin{array}{l}66.571 \\
(0.0000)\end{array}$ \\
\hline $\begin{array}{l}\text { Durbin } \\
\text { Watson }\end{array}$ & 1.90 & 1.99 & 1.63 & 1.80 \\
\hline
\end{tabular}

\section{Conclusion}

According to using valid and reliable data on the sample of 274 companies listed in Tehran Stock Exchange over the 6 years period, we can generalize the results obtained by this study to the statistical population (Tehran Stock Exchange) as regards to probability theory. The results are consistent with prior literature and study expectations. As previously mentioned, first, third and fourth hypothesis are accepted and the second one is rejected. Altogether, main hypothesis is accepted and there is a significant relationship between working capital policy and profitability risk. So, in investment policy, this relationship is negative and in financing policy, it's positive. Therefore, by increasing investment policy that means the firm has a large investment in current assets and uses a conservative policy, profitability risk will decrease. And by increasing financing policy that means the firm has a large amount of current liabilities and uses an aggressive policy, profitability risk will increase. These results are consistent with the prior studies that found that higher investment in working capital is associated with a decreasing in the firm risk. And great amount of current assets and using a conservative policy leads to lower the firm risk.

In this study, we considered size and sales growth as control variables that in all four models, there is a negative relationship between size and profitability risk that when the companies' size increases, profitability risk will decrease. But about the other control variable, there is no significant relationship between sales growth and profitability risk in four regression models.

\section{References}

[1] Anand. M \& Gupta, C., (2001),"Working Capital Performance of Corporate India", Management and Accounting Research, 4(4), 35-65.

[2] Baños-Caballero, S., García-Teruel, P.J., and MartínezSolano, P., (2008), "Working capital management, corporate performance and financial constraints", Working Paper, Department of Management and Finance, Faculty of Economics and Business, University of Murcia, Spain.

[3] Bardia, S.E., (1988),"Working Capital Management", Point Publisher, P56 \& PP84-98.

[4] Chakraborty, Kaushik, (2008), "Working Capital \& Profitability: An Empirical Analysis of Their Relationship With Reference to Selected Companies in the Indian Pharmaceutical Industry", Available at: www.ssrn.com.

[5] Ching, H, Y., Novazzi, A., and Gerab, F., (2011), "Relationship between working capital management and profitability in Brazilian Listed companies", Journal of Global Business and Economics, Volume 3. No 1.

[6] Cote, J.M \& L.K.C,(1999),"The Merchandising Ratio: A Comprehensive Measure of Working Capital Strategy", Accounting Education, 14(2),266. 
[7] Deloof, M., (2003), "Does Working Capital Management Affect Profitability of Belgian Firms?", Journal of Business Finance and Accounting, Vol.30, No.3\&4, PP.573-587.

[8] Dong, H., and Su, J., (2010), "The relationship between working capital management and profitability: A Vietnam case", International Research Journal of Finance and Economics, Issue 49.

[9] Filbeck, G. and Krueger, T., (2005), "Industry Related Differences in Working Capital Management", MidAmerican Journal of Business, 20(2): 11-18.

[10] Gill, A., Biger, N., and Mathur, N., (2010), "The relationship between working capital management and profitability: Evidence from the United States", International Research Journal of Finance and Economics.

[11] Hassanpour, S., (2007), "Effects of Working Capital Strategies on Stock Return", Journal of Financial Accounting, Vol.1, PP.1-19.

[12] Howorth, C. P. Westhead, (2003), "The Focus of Working Capital Management in UK Small Firms", Management Accounting Research 14, Blackwell Publishing, PP.97-111.

[13] Jose, M.L.,Lancaster, C., Stevens,J.L., (1996), "Corporate Return and Cash Conversion Cycle", Journal of Economics and Finance, Vol.20, PP.33-46.

[14] Karaduman, H., H. Akbas and A.d. Caliskan, (2010), "The relationship between working capital management and profitability: evidence from an emerging market", International Research Journal of Finance and Economics, Issue 62.

[15] Kieschenick, R.L., Laplante, M. \& Moussawi, R., (2006), "Working Capital Management and Shareholder Wealth", Available at: http://ssrn.com.

[16] Lazaridis, J., and Tryfondis, D., (2006), "Relationship between Working Capital Management and profitability of listed companies in the Athenes Stock Exchange", Journal of Financial Management Anal., 19:26-35.
[17] Michalski, Grzegorz, (2005), "Liquidity or Profitability: Financial Effectiveness of Investment in Working Capital", Available at: www.ssrn.com

[18] Mohammadzadeh, A., Nofresti, L., (2009), "Effects of Working Capital Policies on Return on Investment in Chemical and Food Industries" Journal of Management Research, Vol.81.

[19] Nazir, M. Afza, T., (2008), "On The Factor Determining Working Capital Requirements", Proceedings of ASBBS, Vol.15, No.1, PP.293-301.

[20] Rajesh, M., and Reddy, V., (2011), "Impact of working capital management on firms profitability", Global Journal of Finance and Management, 3(1): 151-158.

[21] Sarniloglu, F and K. Demirgunes, (2008), "The Effect of Working Capital Management on Firm Profitability: Evidence From Turkey", International Journal of Applied Economics and Finance, 3(7)943-947.

[22] Shin, H., \& Soenen, L., (1998), "Efficiency of Working Capital Management and Corporate Profitability", Financial Practice and Education8, PP.37-45.

[23] Singh, J.P and S. Pandy, (2008), "Impact of working capital management on the profitability", journal of financial Economics, 6(4):62-72.

[24] Solano, M. \& Teruel. J.G.,(2005),"Effects of Working Capital Management on SME profitability", International Journal of Managerial Finance, Vol.3, PP.164-177.

[25] Vural, G., Sokmen, A.G., and Çetenak, E.H., (2012), "Affects of Working Capital Management on Firm's Performance: Evidence from Turkey", International Journal of Economics and Financial Issues, Vol. 2, No. 4, 2012, pp.488-495.

[26] Weinraub, H.J and Visscher, S., (1998), "Industry Practice Relating to Aggressive Conservative Working Capital Policies", Journal of Financial and Strategic Decision, Vol. 11, No. 2, Pp.11-18. 